DOI https://doi.org/10.30525/978-9934-588-92-1-31

\title{
СПРАВЕДЛИВИЙ СУД - ОСНОВА ЗАЛУЧЕННЯ ІНОЗЕМНИХ ІНВЕСТИЦІЙ В УКРАЇНУ
}

\author{
Шелевер Н. В. \\ кандидат юридичних наук, доцент, \\ дочент кафедри адміністративного, \\ фінансового та інформаційного права \\ Ужггородського наиіонального університету \\ м. Ужггород, Украӥна
}

На даний час Україна переживає важкі часи. Війна на Сході України, пандемія коронавірусу COVID-19, корупція, економічна криза зумовлюють відтік іноземних інвестицій. 2020 рік став для всього світу роком випробувань. Для держав, які розвиваються, необхідна підтримка економіки, оскільки вони не готові до таких фінансових витрат.

Іноземні інвестиції є рушійною силою для покращення фінансової ситуації в будь-якій державі. Для того, щоб інвестор мав бажання працювати в чужій державі йому необхідні певні гарантії. Однією 3 таких гарантій $є$ право на справедливий суд, оскільки $є$ можливість захистити своє порушене право. В Україні іноземці мають такі самі права, як і українці та особи без громадянства.

Проблемою на практиці $є$ саме те, що в українських судах процвітає корупція і дуже важко «добитися» саме справедливого правосуддя. Часто судді приймають «замовні» рішення, а роль правосуддя зводиться нанівець. Суди перестають виконувати свою функцію i стають «ручними». Про рівень корупції в українських судах знають в усьому світі.

Значний тиск на іноземних інвесторів чиниться і 3 боку влади. Захист прав фізичних та юридичних осіб від порушень з боку суб'єктів владних повноважень здійснюють адміністративні суди. Проте, як свідчить практика, на них чиниться значний політичний тиск, оскільки однією із сторін по справі є завжди держава. Результат несправедливих рішень - відтік іноземних інвестицій, небажання працювати у державі, де панує свавілля, бюрократія, податковий тиск і корупційні суди.

Проблемним питання на практиці $є$ те, що суддя приймає рішення за своїм внутрішнім переконанням, лише він здійснює остаточну оцінку доказів, висновок експерта має для нього рекомендаційний характер. 
Виходить, що у кожного судді справедливість своя. Реалізація справедливості залежить від правової свідомості та правової культури судді. Тому представниками Феміди мають ставати юристи, які мають високі моральні якості та прагнення здійснювати справедливе судочинство.

«Досвід представлення інтересів іноземних інвесторів у судах України вказує на те, що судові органи допускають неоднакове застосування норм чинного законодавства, а іноді й взагалі не орієнтуються в специфіці норм (в більшості випадків у нормах міжнародних договорів та Конвенціях, ратифікованих Україною), які регулюють процес залучення іноземних інвестицій та їх захисту. Непоодинокі випадки, коли рішення судів грунтуються на вимогах національного законодавства України, при цьому норми міжнародних актів нівелюються» [1].

Для українців Європейський суд 3 прав людини $\epsilon$ еталоном справедливості та останньою надією. Проте, як зазначає П.Д. Гуйван: «Причини небажання Європейського суду з прав людини здійснювати об'єктивне та справедливе правосуддя проти держави України пов'язане 3 неефективністю вердиктів Суду на теренах України та тим, що вони не мають ніякого впливу на здійснення в українському середовищі загальних підходів правотворчого та правозастосовного характеру. Але, серед національних науковців, які досліджують дану проблематику, та адвокатів, котрі займаються представництвом фізичних та юридичних осіб в ЄСПЛ, все частіше публікується інша позиція. Мова йде про відверто корупційні зв'язки між Судом та державою Україна через своїх представників. Здавалося, б ще донедавна про це не можна було б й думати. Але всі є людьми, і усі пороки їм не чужі. В цьому світ переконався, враховуючи недавні корупційні скандали у ФІФА та Раді Європи у квітні 2018 року (до речі, сусіда ЄСПЛ)» [2, с. 507].

Така загроза для іноземного інвестора як з боку національних судів, так і зі сторони ЄСПЛ є неприйнятною. Зрозуміло, що іноземний інвестор буде шукати таку країну, в якій не буде для нього жодного ризику, де саме національні суди будуть здійснювати справедливе судочинство і не буде необхідності звертатися до ЄСПЛ.

«У той же час наявність позитивного рішення національного суду України, рішення ICSID чи рішення Свропейського суду з прав людини не означає, що ваші порушені права вже «поновлено», оскільки постає інше питання - як реалізувати (виконати) таке рішення.

Дійсно, рішення Європейського суду 3 прав людини, ICSID чи відповідного суду України $є$ обов'язковим для сторін та підлягає 134 
обов'язковому виконанню. Проте таке виконання (особливо коли рішення стосується стягнення з України певної суми грошових коштів) може затягнутися на роки. При цьому підставами, на які посилається виконавча служба відмовляючи у виконанні відповідного рішення, в більшості випадків посилається на формальні підстави: неправильно оформлені виконавчі документи, відсутність апостилю на офіційних документах, неправильно оформлена довіреність на представлення інтересів та інші формальні помилки, які допускають представники інвестора. Звісно, такі дії зовсім не на користь інтересам іноземного інвестора» [1].

Такий стан справ призведе у недалекому майбутньому до того, що Україна залишиться наодинці зі своїми проблемами, перетвориться на державу «корупціонерів та пенсіонерів». Необхідний ефективний судовий захист іноземних інвесторів саме зі сторони національних судів, щоб кожний інвестор був упевнений в тому, що його спір в Україні буде розглянутий неупередженим суддею, а рішення суду буде реально виконане.

\section{Література:}

1. Захист прав іноземних інвесторів при здійсненні інвестування в Україні. URL:https://ndipzir.org.ua/wp-content/uploads/2017/07/Boychuk/ 1_5.pdf (дата звернення: 25.10.2020).

2. Гуйван П.Д. Право на справедливий суд: сутність та темпоральні виміри за міжнародними стандартами: монографія. Харків: Право, 2019. $584 \mathrm{c}$. 